\title{
Struggling to Read: Not Just an Urban Problem
}

\author{
Evan Ortlieb, Ph.D. \\ Faculty of Education, Monash University, McMahons Road, Building A \\ Frankston, Victoria 3199 Australia \\ E-mail: evan.ortlieb@monash.edu
}

Accepted: Feb 07, 2013 Published: March 03, 2013

Doi:10.5296/jsr.v4i1.2046 URL: http://dx.doi.org/10.5296/jsr.v4i1.2046

\begin{abstract}
Numerous investigations into urban schools have led towards some determinations regarding what practices/programs are effective; however, modest inquiry into the rural sector of education at all levels has hampered pursuits towards providing students with maximal learning opportunities. How can school board members guide their principals and classroom teachers without basing their instructional programs on research conducted in their own geographic communities? Classroom practitioners know that students come to school with a range of previous experiences and prior knowledge; yet, statewide and national requirements fail to take these notions into consideration. An investigation into particular geographic areas provides relevant information regarding the similarities and differences in how rural and urban schools function to educate their youth.
\end{abstract}

Keywords: Rural Education, School, Geography, Urban, Instruction

\section{Introduction}

Substantial amounts of research have revealed that many inner-city/urban elementary school students struggle in school, particularly in learning to read (Flood \& Anders, 2005; Flint \& Cooter, Jr., 2005; Mason \& Schumm, 2003; Kagan, 2004; Snow, Burns, \& Griffin, 1998); however, the scope of reading problems is more widespread than just inner city schools. "Rural children and youth represent a substantial minority of U.S. students, yet the unique educational needs of rural communities have been largely ignored by the U.S. Department of Education (USDE)," (Arnold, 2005, p. 1). Rural schools are not as often subject to research, even though nearly one-fifth of all students attend rural schools in the United States, according to Why Rural Matters 2005: The Continuing Need for Every State to Take Action on Rural Education. A discussion will follow that addresses the factors related to childhood reading problems to determine what types of reading programs are appropriate for urban and rural areas.

Since the terms rural and urban have varying definitions within particular contexts, the 
constructs used in this investigation will be those which the U.S. Census Bureau (2005) utilizes - that cities or metropolitan areas are composed of at least 50,000 people. Schools located in these districts are considered urban while those districts with fewer residents are deemed rural. For the purpose of this inquiry, the only categories featured will be rural and urban, while subgroups like urban-fringe, suburban, small town, and others have been excluded for analysis purposes.

Students who are raised in varying backgrounds and geographic locations have unique strengths and weaknesses when it comes to reading. Therefore, it is necessary to determine various underlying reasons why rural students, for example, struggle in learning to read. Perhaps, educational funding has prevented rural schools from successfully providing students with the necessary materials, facilities, and specialists. Have school reading programs been fostered to the extent that they are needed in rural areas? Also, does the amount of community involvement correspond to student success in rural settings?

For over 10 years, urban education has been in the limelight of educational research and support for several reasons: 1) federal financial aid has been allocated to schools that qualify for Title 1 (2001) assistance, 2) urban students have been historically neglected or discriminated against and thus, a re-focus in curricular studies has shifted to urban schools, and 3) many state universities have formed partnerships with local urban schools in an effort to research and facilitate necessary reading instructional strategies and implementation (e.g., Louisiana State, Georgia State, Ohio State, Indiana State, Minnesota State, etc.). Further adding to this disparity, "the USDE [continues to use] resources allocated for rural education issues to fund generic programs that are just as applicable to suburban and urban contexts as they are to rural places" (Arnold, 2005, p. 1). Since nearly 8.8 million students attend school in rural educational facilities, it is imperative that these students be given equal opportunities to become educated; and this cannot occur until more research has been conducted specifically on them. Furthermore, designing appropriate intervention plans for rural children is also problematic because of the limited amount of research that has been conducted in these communities (Lerner, 1995). While reading research in urban schools should not be overlooked by rural educators, its validity cannot always be transferred to rural settings. Thus, a closer look into rural schools and the reading difficulties that their students possess is immanently necessary.

\section{Reading Conditions are Crucial}

Children acquire literacy throughout their daily experiences in both formal and informal settings; thus, the reading abilities of many children are influenced by not only their classroom teachers, but also many of their acquaintances. According to Cornelia Flora (1992), literacy was traditionally defined "in functional terms that explored how well adults applied reading and writing skills to everyday situations" (p. 290). Although literacy definitions vary between societies, literacy is now typically understood as having abilities to read and write at a level adequate for written communication and functionality within society. 
According to Bronfenbrenner (1979), it is imperative to investigate many contexts when studying a child's development. Moreover, an analysis of such contexts as a child and his/her peers, familial members, and child care teachers suggests that these interactions indicate an environment's developmental potential (Weigel, Martin, \& Bennett, 2005). To further relate Bronfenbrenner's ecological theory to school-age children, McNaughton (1995) found positive and negative correlations of reading potential are based on the notion that "development is enhanced by the degree to which environments are well coordinated in terms of practices, activities, and systems of learning and development" (p. 12). Hence, reading abilities are influenced holistically.

Traditionally, research of literate home environments focused on the reading aloud of books to children, better known as shared reading time. This concept is important to a child's acquisition of literacy; however, recent research including that of Burgess, Hecht, and Lonigan (2002) reveals that there are several other factors that contribute to a child's literacy development, including the parents' literacy levels, reading habits, and involvement in children's literacy activities.

A parent's low level of literacy can be a potential indicator for a student having a limited literacy environment, reading difficulties, and language development. Without having a parent who can read, a student is severely limited in regard to the time allotted and spent on reading within the house. According to Burgess et al. (2002), children who have difficulties in reading were more likely to have parents with below-average reading abilities. This cyclic performance trend often reoccurs for several generations of familial lineage.

In addition to parents' literacy levels, parental reading habits also contribute to the overall literacy environment. Parents who do not own any books and spend very little if any time reading set an example for their children. The 'I never read' model can be found all too often in households, especially with the rise in technological applications. According to a study conducted by the Henry J. Kaiser Family Foundation (2003), children age zero to six spend triple the amount of time (118 minutes) with television, computers, and video games as they spend reading or being read to (39 minutes). In return, children are less likely to allot their free time to engage in reading, frequently leading them to value reading as less important or intrinsically rewarding because it is not valued in the home setting. Instead, children will utilize their time engaging in other activities that are more suitable in their households.

On the other hand, those parents/caregivers who model reading and view the act of reading as rewarding and worthwhile often have children who hold those same beliefs. These parents prioritize securing reading materials/resources for their children's use including library books, owned texts, newspaper subscriptions, children's magazines, etc. This exposure to print at an early age is a key factor in the overall success of a student in elementary school. By the time students enter into primary school, those students who have already been exposed to various forms of print within the home environment can connect more easily with the forms of print 
found in schools. Together, home and school environments can essentially work in unison to emphasize and reiterate the importance and value of reading.

Burgess et al. (2002) stated that parental activities can be classified as those behaviors that "directly engage a child in activities designed to foster literacy or language development" ( $p$. 413). One such activity is joint book reading. In a study completed by Whitehurst \& Lonigan (1998), joint book reading and parental reading were found to positively contribute to "preschool-age children's receptive and expressive language abilities" (Weigel, Martin, \& Bennett, 2005, p. 208). These students also outperformed their peers during school reading exercises like shared reading and guided reading.

\section{Reading: An Indicator of Academic Success}

The difficulties of all students are not limited to reading per se; however, reading serves as a foundational skill to all subject areas, and thus is the focus of this study. Of the nation's fourth graders who attend schools in urban locations, $21 \%$ have failed to reach the basic proficiency level in reading, according to a 2003 National Assessment of Educational Progress (NAEP) Report. Having the below-basic reading level indicates that a student is not capable of reading for functional purposes at this grade level. In addition to having many more students being below-average readers in urban communities, these schools have traditionally failed to address the reading problems of poor, minority students (Hettleman, 2003 , p. 7). These are alarming developments when aligned with Good, Gruba, \& Kaminski's (2001) notion that students who read below average in elementary school remain poor readers throughout schooling (Cartledge \& Musti-Rao, 2005). "One of the most powerful indicators of later academic success is a child's reading level at the end of third grade," according to the Northern California Council for the Community (2003, para. 1). This premise is based on the idea that reading is a fundamental aspect of virtually every content area.

\section{What's Being Done in Urban Areas?}

Nevertheless, within the last decade, initiatives have been established in an attempt to halt any future decline in achievement and allow students more opportunities to succeed. In 1998, the National Research Council (NRC) released a report arguing for better teacher preparation and stressed the importance of reading specialists (Snow, Burns, \& Griffin, 1998). In a Press Release of this report from March 19, 1998, Catherine Snow, a professor of education at Harvard Graduate School of Education, commented that, "We need the will to ensure that every child has access to excellent preschool environments and well-prepared teachers." The University of Chicago Center for Urban School Improvement put forth the 2001 Reading Initiative to begin a professional development series for new reading specialists. These Reading Initiatives allowed teachers to gain the skills needed to teacher-train fellow staff members at their own schools. In addition, teachers learned how to construct school-wide reading plans. 


\section{Rural Education Difficulties}

It is essential that research be conducted in rural school environments because the difficulties that rural elementary school teachers face each day differ from those of urban educators. Local research has yet to be facilitated on a widespread basis, even though the idea that variation exists in rural and urban reading problems dates back to the nineteenth century. In 1880, a visiting superintendent inspected one rural school, finding that it suffered because of its misuse of the school library. Instead of utilizing the library as a hall of records, Fargo (1931) states libraries should be "filled with fresh looking books [that] displace the age-old archives; fresh paint, low bookcases, and well-filled magazine racks . . . and half a dozen tables with comfortable chairs tempted to loitering" (p. 6). However, individual rural schools did not have the funding to afford these materials. Fargo posited, "The answer to the rural school reading problem is consolidation. Alongside the consolidated school, the consolidated library [sic]" (p. 6). Essentially, struggling readers could focus on basic reading skills with close supervision. Meanwhile better readers "may be introduced to the varied picture books and primers provided by the school library with the assurance [of keeping] their own interest" (Fargo, p. 3). The theme of rural school consolidation is still popular today.

Jordan \& Jordan (2004) state that "rural schools have been geographically and politically isolated to the extent that some might say that they have been the victims of $\ldots$ an unstated governmental policy of benign neglect" (p. 1). In the mid-1900s, rural areas could not provide students with the same quality of schools as those found in urban areas for lack of teacher training, community assistance, and monetary support. In accordance, governments formed policies, attempting to consolidate these rural schools into larger centralized institutions. As a result of diverting funds away from smaller rural academic establishments, rural schools continue to fall short of national expectations set by the No Child Left Behind Act of 2001. The most persistent problems of illiteracy can be found in the regional areas of the South, Southwest, and Appalachia (Flora, 1992).

Although illiteracy awareness is crucial for progress, rural communities are often bound by other factors, which prevent them from addressing this significant issue. The Federal and many state governments have allotted funding for programs to be directed at the substantial problem of illiteracy; however, these limited amounts of financial support do little to improve the already difficult task of confronting this issue in very diverse and sparsely-populated regions. In 2004, Jordan \& Jordan further proclaimed:

If education is a state responsibility, then in an era of state-mandated standards and assessments, the state has an inherent responsibility to ensure that students have access to the human and material resources required for them to meet standards and pass state proficiency examinations. (p. 1)

In general, it takes additional resources to reach the same number of people in rural locations when compared with people who live closer together like urban dwellers. "The resources 
readily available to metropolitan providers-libraries, material and equipment suppliers, training opportunities, the support of specialists and professional associations-require significant effort by rural providers who must travel great distances for similar opportunities" (Beach, 1995).

In addition to the limited financial assistance that rural communities receive, many community members are not always willing to consistently participate in literacy programs for extended amounts of time. Many agrarian workers in rural areas cannot appropriate time from their schedules, since they often work from dawn to dusk. Still, efforts have been made to reach out to these populations by establishing local educational programs. According to Flora (1992), "most rural literacy programs are extremely fragile - dependent on the stamina of one or two very dedicated individuals" (p. 292). Yet, with "more than 50 percent of rural fourth grade children read[ing] below grade level, as compared to the national average of 38 percent," it is imperative that these types of programs be continued (The Annie E. Casey Foundation, 2004). According to the Save the Children Foundation (2005), rural students who participate in these types of after-school programs are two and a half times more likely to pursue higher education. Unfortunately, many programs are at best moderately successful in reaching a substantial number of residents in these segmented areas.

\subsection{How do rural educators progress from here?}

Rural communities have long been ignored when it comes to assistance programs; however, the federal government is currently appropriating financial contributions to schools who qualify for the Rural and Low-income School Initiative (RLIS). Nationally, schools have been granted $\$ 85,312,000$; still, just $\$ 5,337,158$ was directed to local schools in Louisiana, for example, during the fiscal year of 2005-2006, according to the U.S. Department of Education. Rural school children are more likely to face failure because of crime, substance abuse, parental neglect or other factors than city or suburban kids" (Five Million Children, 1990). A report conducted by Helge (1990) surprised many people who envisioned rural life as being free from the many difficulties of urban life. In fact, one in seven rural Americans is poor, stated Todd Post (2005), and at some point each year nearly a third of rural residents are food insecure. Organizations like the National Rural Education Association (NREA) have established programs like the Rural Education Achievement Program (REAP), the Rural School and Community Trust, and the E-Rate Program to expand services directed into the rural sector of educational institutions on a nationwide scale. According to the Organizations Concerned about Rural Education (OCRE) report entitled, REAP, E-Rate Help Rural Schools with NCLB:

Congress created REAP in 2002 with an appropriation of $\$ 162.5$ million. Although President Bush proposed ending REAP when he submitted his 2003 and 2004 budgets to Congress, bipartisan coalitions in the House and Senate saved the program. The REAP appropriation was $\$ 167.7$ million in 2003 and $\$ 167.8$ million in 2004. Of some 6,000 U.S. schools that are eligible to receive REAP funds, 4,026 applied for and received 
funding in 2003 (para. 7).

These programs continue to serve a vital function within rural schools across the nation; yet, they are also heavily dependent upon locals to carry out the workload. Thus, the success of these programs can sway from greatly benefiting rural students to not helping at all.

Establishing local reading-based programs frequently proves more effective than simply receiving monetary assistance through grants from the federal government. During the year, 2001, in Starkville, Mississippi, the Promising Readers Program was developed to provide students who were considered to be struggling between $\mathrm{K}-3^{\text {rd }}$ grades from local, rural schools with after-school tutoring and reading assistance (Boutwell, Brenner, \& Jayroe, 2002).

Funded by the Reading Excellence Act, "Promising Readers is a literature-based program that engages children in frequent reading ... small group skill and strategy instruction, and one-on-one reading," stated Boutwell et al. (2002, para. 3). The program began with an enrollment of 50 children; in addition, preservice teacher candidates, parents, and other family members were encouraged to assist in coordinating this reading program.

Four members of the staff conducted field research and documented details of the program during the first year. In addition, they conducted interviews, surveys, and kept journals, audiotapes, and videotapes. After a thorough analysis was conducted, several benefits were discovered. Parents were eager to work with the program, especially when offered a stipend to support their expenditures. Boutwell et al. (2002) stated that over time, parents and volunteers became skilled in the tutoring process. Parents transitioned from a subordinate role in the program to suggesting possible improvements and strategies for the children to use. Parents wanted to learn more and more strategies so they could take the lessons beyond the confines of the school, and implement them at home with their children. Also, parents became further involved with other functions of the school, including the Parent-Teacher Association (PTA).

Although there was a wealth of positive experiences associated with the Promising Readers Program, there were also some challenges that surfaced. Sometimes, parents inconsistently attended the after-school sessions. Others stopped coming all together because of various reasons like work and transportation issues. "Cultural differences also presented challenges for a program striving to create a particular kind of literature-based learning environment," according to Boutwell et al. (2002, para. 5). For example, the teachers wanted parents to use school types of management when confronting their students like time-out or simply trying to redirect their behavior. However, parents sometimes resorted to yelling or even spanking the children to get them to obey.

Besides the Promising Readers Program, other reading programs designed for rural areas have been established on a larger scale. The America's Reading Corps establishes local-based reading programs by organizing one million tutors, who give individualized after-school 
tutoring for three million children, ranging from pre-K to third grade. In this effort, 30,000 reading specialists and coordinators train one million other volunteers who work with teachers, principals, and librarians to improve students' reading abilities (America Reads Challenge, 1996). In a rural school district in Kentucky, the AmeriCorps SLICE program was instituted to provide one-on-one tutoring services to students at-risk for reading failure. Twenty-five AmeriCorps trained volunteers provided assistance to 128 second graders four times a week for a duration of nine months. Based on scores from pre- and post-tests of an informal reading inventory, tutored students demonstrated an average improvement of 2.8 grade levels in reading comprehension. AmeriCorps members visited the students' homes weekly to update their parents and give advice for further parent/guardian facilitation in reading. This project was funded by a portion of the 2.75 billion dollars allocated by the federal government's America Reads Challenge program.

Rural school problems persist because these schools are not only isolated by their geographic location but also impeded by communication. Although it is difficult to regularly stay in contact with other schools, it is necessary. Together, rural schools must commit to research, share their findings with other teachers and schools, and adjust their instruction accordingly. In addition, more research needs to take place nationally so that the needs of rural communities become evident and change can occur. How can rural schools successfully accomplish these tasks? Both federal and state governments must appropriate necessary funding so that all children have an equal opportunity to become schooled and in the process, learn to read. These funds would supply schools with up-to-date reading materials, continual teacher development programs, guides and supplies for parents/guardians to further facilitate reading instruction at home, and designate at least one reading specialist per school district. With these advances, rural schools should see a reduction in the number of students with persistent reading difficulties and in turn, many students will become better equipped to excel in a print-dominant society.

Today, the need for reading programs has finally been recognized at all levels of government. In return, early intervention programs have been enacted in schools which meet the low-income requirements. Based on the idea that prevention is a more appropriate strategy than fixing reading problems after they are neglected, programs like Head Start, High Scope, First Steps, and Reading First were created.

Head Start is a national reading program that assists preschoolers and kindergarteners from low-income families. High Scope, also known as the Perry Preschool Program, centers on the idea of language development and acquisition. High Scope is based on the notion of Piaget's theories of child development; thus, a student can acquire certain abilities at particular ages. Meanwhile, the First Steps Program has a similar format as Reading Recovery: a one-on-one tutoring program based on a series of leveled books (Cartledge \& Musti-Rao, 2005). Reading First addresses "the needs of struggling and non-readers, thereby improving reading achievement and outcomes for students in Louisiana and reducing the illiteracy rate in the state ... [and eventually creating] a Comprehensive PreK-12 State Reading Plan" (Louisiana 
Department of Education, 2003).

Some school districts have begun "Big Buddy Programs," which allow older students from high school and college to mentor, tutor, and read with elementary school students on a bi-weekly basis. These programs have several benefits including: elementary school students have the opportunity to listen to someone model reading, the importance of reading is reinforced outside the classroom setting, and students get to practice reading. Although there are a number of positive factors in regard to Big Buddy

Programs, tutoring does not always increase a student's reading ability. According to the NRC Report (1998), volunteer tutors are beneficial by giving children opportunities to read for fluency, but are unlikely to assist those children with severe reading problems.

\section{References}

Arnold, M. L. (2005, April 3). Rural education: A new perspective is needed at the U.S. Department of Education. Journal of Research in Rural Education, 20(3). Retrieved November 19, 2011, from http://www.umaine.edu/jrre/20-3.pdf

Beach, B. (1995). Providers' perspectives on rural child care. Unpublished manuscript.

Beeson, E., \& Strange, M. (2005, February). Why rural matters 2005: The continuing need for every state to take action on rural education. (Available from

Communications Department, Rural School and Community Trust, Suite 703, 1825 K Street, N.W., Washington, DC 20006)

Boutwell, A., Brenner, D., \& Jayroe, T. (November, 2002). Working with families in the rural South: Findings from the REA-funded Promising Readers Program. Research Digest. $\begin{array}{llll}\text { Retrieved October } & \text { 13, 2011, from }\end{array}$ http://www.gse.harvard.edu/hfrp/projects/fine/resources/digest/working.html2

Bronfenbrenner, U. (1979). The ecology of human development: Experiments by nature and design. Cambridge, MA: Harvard University Press.

Burgess, S.R., Hecht, S.A., \& Lonigan, C.J. (2002). Relations of the home literacy environment (HLE) to the development of reading-related abilities: A one-year longitudinal study. Reading Research Quarterly, 37, 408-426.

Cartledge, G. \& Musti-Rao, S. (2005). Urgent, intense instruction: Preventing reading failure in the kindergarten, first grade urban learner. Paper presented at a P-12 Project Conference, Columbus, $\mathrm{OH}$.

Division of Student Services and Federal Programs. (September 9, 2005). Title I: Frequently 
asked questions. Retrieved November 20, 2011, from

http://www.sdhc.k12.fl.us/ supportive.services/titleI.htm

Fargo, L. (1931). The superintendent makes a discovery: The answer to the rural school reading problem. Chicago: American Library Association.

Flood, J. \& Anders, P. (Eds.) (2005). Literacy development of students in urban schools: Research and policy. Newark, DE: International Reading Association.

Flora, C.B. (1992). The new poor in midwestern farming communities. In Duncan, C. (Ed.), Rural Poverty in America. New York: Auburn House, 201-214.

Flora, C.B., Flora, J.L., Spears, J.D., Swanson, L.E. (1992). Rural communities: Legacy and change. Boulder, $\mathrm{CO}$ : Westview Press.

Flynt, E. \& Cooter, Jr., R. (2005). Improving middle-grades reading in urban schools: The Memphis Comprehensive Framework. The Reading Teacher, 58, 774-780.

Good, R. H., Gruba, J., \& Kaminski, R. A. (2001). Best practices in using Dynamic Indicators of Basic Early Literacy Skills (DIBELS) in an outcome-driven model. In A. Thomas \& J. Grimes (Eds.), Best Practices in School Psychology IV (pp.679 -700). Washington, DC: National Association of School Psychologists.

Helge, D. (1990). A national study regarding at-risk students. Bellingham, WA: Western Washington University, National Rural Development Institute. (ERIC Document Reproduction Service No. ED 324 178)

Henry J. Kaiser Family Foundation (2003). New study finds children age zero to six spend as much time with TV, computers, and video games as playing outside. Washington, D.C., Retrieved November 13, 2005, from http://www.kff.org/entmedia/entmedia102803nr.cfm

Hettleman, K.R. (2003). The invisible dyslexics: How public school systems in Baltimore and elsewhere discriminate against poor children in the diagnosis and treatment of early reading difficulties. Baltimore, MD: The Abell Foundation.

Jordan, T. \& Jordan, K. (Fall 2004). Rural research brief: Rural schools under scrutiny. The Rural Educator, 26(1), 1-5.

Kagan, S. (2004). Improving urban student achievement through early childhood reform: What state policymakers can do. Early Childhood Reform Issue from the Education Commission of the States. Retrieved October 28, 2005, from http://www.ecs.org/clearinghouse/50/07/5007.htm 


\section{I Macrothink}

Journal of Sociological Research

ISSN 1948-5468

2013, Vol. 4, No.1

Lerner, R.M. (1995). America's youth in crisis: Challenges and opportunities for programs and policies. Thousand Oaks, CA: Sage Publications.

Louisiana Department of Education (2003). PreK-12 Statewide Reading Plan. Retrieved November 21, 2011, from http://www.doe.state.la.us/lde/ssaa/1316.html

Mason, P. \& Schumm, J. (2003). Promising practices for urban reading instruction. Newark, DE: International Reading Association.

McNaughton, S. (1995). Patterns of emergent literacy: Processes of development and transition. Melbourne, VIC, Australia: Oxford University Press.

National Center for Children in Poverty. (1990). Five million children: A statistical profile of our poorest young citizens. New York: Columbia University.

National Center for Education Statistics. (2005). National Assessment of Educational Progress (NAEP) Report. (2003). [Data file]. Available from 350 Main Street, Malden, MA 02148-5023, 781-338-3000, or www.doe.mass.edu

Northern California Council for the Community. (2003). School readiness and academic success: Relevant indicators. Retrieved November 21, 2011, from http://www. ncccsf.org/report/school-readiness.htm

Organizations Concerned about Rural Education (OCRE). (2005). REAP, E-Rate help rural schools with NCLB. Retrieved November 12, 2005, from http://www.rural schools.org/news/letter.html

Post, T. (April, 2005). Strengthening rural communities. Washington, D.C.: Bread for the World Institute. Retrieved October 28, 2011, from http://www.bread.org/issues/backgroundpapers/2005/april_hunger_report_2005.htm

Snow, C. E., Burns, S. M., \& Griffin, P. (Eds.) (1998). Preventing reading difficulties in young children, Chapter 4: Predictors of Success and Failure in Reading. National Research Council, National Academy of Sciences. Retrieved October 22, 2005, from http://www4.nationalacademies.org/news.nsf/isbn/030906418X?Open Document

The Annie E. Casey Foundation. (2004). City and rural: Kids count data book. Baltimore, MD: Population Reference Bureau. Retrieved December 7, 2005, from http:// www.aecf.org/kidscount/rural_databook/entire_city_rural_databook.pdf

The University of Illinois at Chicago (UIC) Center for Literacy. (2005). The 2001 reading initiative. [Data file]. Available from: 1040 West Harrison (MC 147) - Chicago, IL 60607-7133, 312-413-1914. 
U.S. Census Bureau, Population Division, Population Distribution Branch. About

metropolitan and micropolitan statistical areas. (1980, 2000). [Data file]. Retrieved November 5, 2011, from http://www.census.gov/population/www/ estimates/aboutmetro.html

U.S. Department of Education. (1999). The reading excellence act. Questions and Answers. Retrieved November 22, 2011, from http://www.ed.gov/inits/FY99/q-read.html

Weigel, D., Martin, S., \& Bennett, K. (2005). Ecological influences of the home and the child-care center on preschool-age children's literacy development. Reading Research Quarterly, 40, 204-233.

Whitehurst, G. J., \& Lonigan, C. J. (1998). Child development and emergent literacy. Child Development, 69, 848-872. 